\title{
INTEGRASI PENDIDIKAN KARAKTER DALAM PEMBELAJARAN INOVATIF DI SEKOLAH DASAR
}

\author{
Abdul Mu'min Saud, M.Pd \\ Universitas Pasundan \\ abdulmumin.saud@yahoo.com
}

\begin{abstract}
The development of science, technology and information (science and technology) is very fast and globalization nowadays occur positive and negative impacts on people's lives, both individual and social life. The positive impact of the development of science and technology and the globalization of the labor market is opening opportunities in accordance with the needs of society and the state. While the negative impact is the changing values and norms of life that is often in contradiction with the norms and values of life that has existed in the community. In this context, education, especially primary education, plays a very important to preserve and protect the norms and positive life values that already exist in the society of a country from the negative effects of science and technology development and globalization. The education process is right and quality provided supplies and power to maintain the "identity" of the negative effects of globalization, not only for the interests of individual learners, but also for the benefit of society and the state. National policy development of the noble character education into the national education system is a strategic effort to equip future generations with the noble character of the nation as the identity of Indonesia in global competition. With the character education that is applied systematically and sustainably, a child will be emotionally intelligent. Emotional intelligence is important provision in preparing children to meet the future, because someone will be more easily and successfully face all kinds of life challenges, including the challenge to succeed academically.
\end{abstract}

Keywords: integration of character education, innovative learning, elementary school

\section{ABSTRAK}

Perkembangan ilmu pengetahuan, teknologi dan informasi (IPTEK) yang sangat cepat serta globalisasi yang dewasa ini terjadi berdampak positif dan negatif terhadap kehidupan masyarakat, baik kehidupan individu maupun sosial kemasyarakatan. Dampak positif dari perkembangan IPTEK dan globalisasi tersebut adalah terbukanya peluang pasar kerja sesuai dengan kebutuhan masyarakat dan negara. Sedangkan dampak negatifnya adalah terjadinya perubahan nilai dan norma kehidupan yang seringkali kontradiksi dengan norma dan nilai kehidupan yang telah ada di masyarakat. Dalam konteks inilah, pendidikan khususnya pendidikan dasar, berperan sangat penting untuk memelihara dan melindungi norma dan nilai kehidupan positif yang telah ada di masyarakat suatu negara dari pengaruh negatif perkembangan IPTEK dan globalisasi. Proses pendidikan yang benar dan bermutu memberikan bekal dan kekuatan untuk memelihara "jati diri" dari pengaruh negatif globalisasi, bukan hanya untuk kepentingan individu peserta didik, tetapi juga untuk kepentingan masyarakat dan negara. Kebijakan nasional pengembangan pendidikan karakter 


\section{Didaktik : J urnal Pendidikan Guru Sekolah Dasar, ISSN : 2477-5673 \\ Sekolah Tinggi Keguruan dan Ilmu Pendidikan Subang \\ Volume I Nomor 1, Desember 2015}

mulia dalam sistem pendidikan nasional merupakan upaya stratejik untuk membekali generasi masa depan dengan karakter mulia bangsa sebagai jati diri bangsa Indonesia dalam persaingan global. Dengan pendidikan karakter yang diterapkan secara sistematis dan berkelanjutan, seorang anak akan menjadi cerdas emosinya. Kecerdasan emosi ini adalah bekal penting dalam mempersiapkan anak menyongsong masa depan, karena seseorang akan lebih mudah dan berhasil menghadapi segala macam tantangan kehidupan, termasuk tantangan untuk berhasil secara akademis.

\section{Kata kunci : integrasi pendidikan karakter, pembelajaran inovatif, sekolah dasar}

\section{A. Menuju Pendidikan Karakter Anak Usia Pendidikan Dasar}

Guru merupakan salah satu faktor kunci dalam meletakkan dasardasar, yang kokoh bagi pembentukan karakter generasi bangsa yang mulia melalui pembelajaran inovatif sesuai dengan perkembangan mental psikologis peserta didik pada setap jenis dan jenjang pendidikan formal. Pemahaman guru yang komprehensif tentang konsep dan jenis pembelajaran inovatif dalam pendidikan karakter mulia di sekolah merupakan modal dasar dalam mencapai tujuan pendidikan karakter mulia secara efektif.

Karakter adalah ciri khas kepribadian, sikap dan perilaku keseharian seseorang sebagai akumulasi dari pembawaan, kebiasaan dan proses pendidikan yang diikuti, sehingga menjadi ciri khas yang membedakan dengan orang lain. Karakter mulia berarti individu yang memiliki pengetahuan tentang potensi dirinya, ditandai dengan nilai-nilai seperti reflektif, percaya diri, rasional, logis, kritis, analitis, kreatif dan inovatif, mandiri, hidup sehat, bertanggung jawab, cinta ilmu, sabar, berhati-hati, rela berkorban, pemberani, dapat dipercaya, jujur, menepati janji, adil, rendah hati, malu berbuat salah, pemaaf, berhati lembut, setia, bekerja keras, tekun, ulet/gigih, teliti, berinisiatif, berpikir positif, disiplin, antisipatif, inisiatif, visioner, bersahaja, bersemangat, dinamis, hemat/efisien, rnenghargai

waktu, pengabdianldedikatif, pengendalian diri, produktif, ramah, cinta keindahan (estetis), sportif, tabah, terbuka, tertib. Individu juga memiliki kesadaran untuk berbuat yang terbaik atau unggul, dan individu juga mampu bertindak sesuai potensi dan kesadarannya tersebut. Karakteristik adalah realisasi perkembangan positif sebagai individu (intelektual, emosional, sosial, etika, dan perilaku).

Individu yang berkarakter baik atau unggul adalah seseorang yang berusaha melakukan hal-hal yang terbaik terhadap Tuhan YME, dirinya, sesama, lingkungan, bangsa dan negara serta dunia internasional pada umumnya dengan mengoptimalkan potensi (pengetahuan) dirinya dan disertai dengan kesadaran, emosi dan motivasinya (perasaannya). Karakter dan perilaku seseorang terbentuk melalui aktivitas proses pendidikan di sekolah madrasah, kehidupan di rumah, dan kehidupan di masyarakat. Pendidikan karakter adalah suatu sistem penanaman nilai-nilai karakter kepada peserta didik yang meliputi komponen pengetahuan, kesadaran atau kemauan, dan tindakan untuk melaksanakan nilai-nilai tersebut. Pendidikan karakter dapat dimaknai sebagai "the deliberate use of all dimensions of school life to foster optimal character development". 
Pendidikan karakter berpijak dari karakter dasar manusia, yang bersumber dari nilai moral universal (bersifat absolut) yang bersumber dari agama yang juga disebut sebagai the golden rule. Pendidikan karakter dapat memiliki tujuan yang pasti, apabila berpijak dari nilai-nilai karakter dasar tersebut. Menurut para ahli psikolog, beberapa nilai karakter dasar tersebut adalah: cinta kepada Allah dan ciptaan-Nya (alam dengan isinya), tanggung jawab, jujur, hormat dan santun, kasih sayang, peduli, dan kerjasama, percaya diri, kreatif, kerja keras, dan pantang menyerah, keadilan dan kepemimpinan; baik dan rendah hati, toleransi, cinta damai, dan cinta persatuan. Pendapat lain mengatakan bahwa karakter dasar manusia terdiri dari: dapat dipercaya, rasa hormat dan perhatian, peduli, jujur, tanggung jawab; kewarganegaraan, ketulusan, berani, tekun, disiplin, visioner, adil, dan punya integritas. Penyelenggaraan pendidikan karakter di sekolah harus berpijak kepada nilai-nilai karakter dasar, yang selanjutnya dikembangkan menjadi nilai-nilai yang lebih banyak atau lebih tinggi (yang bersifat tidak absolut atau bersifat relatif) sesuai dengan kebutuhan, kondisi, dan lingkungan sekolah itu sendiri.

Pendidikan karakter memiliki esensi dan makna yang sama dengan pendidikan moral dan pendidikan akhlak. Tujuannya adalah membentuk pribadi anak, supaya menjadi manusia yang baik, warga masyarakat, dan warga negara yang baik. Adapun kriteria manusia yang baik, warga masyarakat yang baik, dan warga negara yang baik bagi suatu masyarakat atau bangsa, secara umum adalah nilai-nilai sosial tertentu, yang banyak dipengaruhi oleh budaya masyarakat dan bangsanya. Oleh karena itu, hakikat dari pendidikan karakter dalam konteks pendidikan di Indonesia adalah pendidikan nilai, yakni pendidikan nilai-nilai luhur yang bersumber dari budaya bangsa Indonesia sendiri, dalam rangka membina kepribadian generasi muda. Adapun indikator utama karakter bangsa Indonesia, diantaranya: Religious (beriman dan bertaqwa); Ramah dan santun kepada yang lebih tua, sesama, dan lebih muda; Jujur kepada diri sendiri, orang lain, dan Tuhan yang diyakininya; Mengutamakan kepentingan umum dalam kehidupan bermasyarakat; Musyawarah dan mufakat demi kemaslahatan umum.

Pengembangan program belajar pendidikan dasar harus dikaitkan dengan karakteristik kualitas sumber daya manusa yang diperlukan untuk kehidupan mereka di masyarakat, dan sekaligus mempertimbangkan karakteristik perbedaan kelompok peserta didik di masing-masingjenis danjenjang satuan pendidikan dasar. Konsep dasar yang komprehensif dan luas tentang fungsi pokok pendidikan dasar tidak hanya dipergunakan untuk masyarakat, tetapi hendaknya tertuju pada suatu kajian tentang praktek dan kebijakan pendidikan dasar pada tingkat awal dari semua negara yang memberikan suatu landasan yang mantap bagi praktek belajar peserta didik di masa depan, dan sekaligus mengembangkan keterampilan hidup (life skills) yang esensial untuk menghidupi sebuah kehidupan yang konstruktif dalam masyarakat.

Dalam menghadapi harapan dan tantangan masa depan yang lebih baik, pendidikan dipandang sebagai esensi kehidupan, baik bagi perkembangan pribadi maupun perkembangan masyarakat. Misi pendidikan, termasuk pendidikan dasar, adalah memungkinkan setiap 
orang, tanpa kecuali, mengembangkan sepenuhnya semua bakat individu, dan mewujudkan potensi kreatifnya, termasuk tanggung jawab terhadap hidup sendiri, dan pencapaian tujuan pribadi. Misi ini akan dapat tercapai dengan melalui strategi yang disebut belajar sepanjang hidup (learning throughout life), yang dipandang sebagai detak $\mathrm{j}$ antung dari masyarakat. Dengan mengikuti gagasan konsep belajar sepanjang hidup, maka pengembangan program pendidikan dasar harus memberikan tekanan yang lebih besar pada salah satu dari empat pilar yang diusulkan dan digambarkan sebagai dasar pendidikan, yaitu: belajar hidup bersama (learning to live together). Dalam pola ini, pendidikan dilakukan dengan mengembangkan suatu pemahaman tentang orang lain, sejarah, tradisi, dan nilai-nilai spiritual mereka. Dengan bertopang pada landasan tersebut, pendidikan dasar dapat menciptakan suatu semangat baru yang dibimbing oleh kesadaran tentang resiko atau tantangan masa depan, sehingga mendorong orang melaksanakan proyek bersama atau mengelola konflik yang pasti terjadi, dengan suatu cara yang bijaksana dan damai.

Untuk mendukung terwujudnya gagasan tersebut di atas, maka strategi awal pengembangan program pendidikan dasar adalah penekanan kepada pilar pertama dari 4 (empat) pilar pendidikan yang ditetapkan UNESCO, yaitu belajar mengetahui (learning to know). Adanya perubahan yang cepat yang dibawa oleh kemajuan ilmiah dan norma-norma baru tentang kegiatan ekonomi dan sosial, tekanan pada belajar untuk hidup bersama dipadukan dengan suatu pendidikan umum yang cukup luas dengan melalui belajar memperoleh pengetahuan sebagai alat untuk memahami hidup. Belajar bekerja (learning to do) adalah pilar pendidikan yang selanjutnya harus dipelajari oleh peserta didik pendidikan dasar. Disamping belajar bekerja melakukan sesuatu pekerjaan, secara lebih umum perlu pula menguasai kemampuan yang memungkinkan orang mampu menghadapi berbagai situasi yang sering tidak dapat diduga sebelumnya, dan bekerja dalam berbagai tim. Akhirnya, pilar pendidikan yang keempat yang harus dipelajari peserta didik pendidikan dasar adalah belajar menjadi dirinya sendiri (learning to be). Hal ini berarti bahwa program belajar pendidikan dasar harus memfasilitasi peserta didikm untuk belajar lebih bebas dan mempunyai pandangan sendiri yang disertai dengan rasa tanggung jawab pribadi yang lebih kuat untuk mencapai tujuan hidup pribadinya atau tujuan bersama sebagai anggota masyarakat.

Untuk mencapai tujuan pendidikan yang bermutu untuk seluruh lapisan peserta didik pendidikan dasar, maka program belajar harus dirancang sebagai keseluruhan dari penawaran lembaga pendidikan (sekolah) termasuk kegiatan di luar kelas/sekolah dengan rangkaian mata pelajaran dan kegiatan yang terpadu. Setiap satuan pendidikan memperoleh identitas atas dasar caranya mereka menjalankan program-program belajar yang dikembangkannya. Faktor-faktor yang menentukan isi tiap program harus muncul jauh di luar batas-batas sekolah/satuan pendidikan. Faktorfaktor itu timbul melalui kekuatankekuatan sosial, kultural, ekonomi, dan konsep politik. Program belajar suatu sekolah/satuan pendidikan dasarr harus mewakili keseluruhan 
sistem pengaruh yang membangun lingkungan belajar bagi peserta didik. Program itu sendiri terdiri atas unsurunsur tertentu yang mencakup maksud dan tujuan, kurikulum, metode pembelajaran, dan evaluasi hasil belajar peserta didik.

Pengembangan program belajar pada tingkat pendidikan dasar harus meliputi hal- hal esensial yang dibutuhkan peserta didik, seperti: bidang-bidang studi apa yang akan disajikan; untuk maksud-rnaksud khusus apa bidang studi tersebut disajikan; bagaimana bidang studi terse but hendak disusun dan dihubung-hubungkan; dan bagaimana bidang studi tersebut diajarkan kepada peserta didik. Dengan kata lain, program belajar pendidikan dasar harus dikembangkan secara terpadu dan berlandaskan kepada pengembangkan kemampuan pemecahan masalah kehidupan yang perlu dikuasai pesrta didik. Secara khusus tujuan pokok pendidikan karakter bagi anak usia pendidikan dasar adalah:

Meletakkan dasar-dasar perilaku dan karakter yang kokoh sebagai pribadi maupun anggota masyarakat untuk menghadapi berbagai perubahan dalam kehidupan siswa di masa depan; Membiasakan perilaku dan ucapan yang sesuai dan diterima berbagai pihak dalam kegiatan sosial kemasyarakatan; Membangun kemampuan "self discipline" yang adaptif bagi siswa sesuai dengan karakter bangsa untuk hidup layak dan terhormat. Adapun substansi pendidikan karakter bagi siswa usia pendidikan dasar adalah:

Pembiasaan bertatakrama yang sesuai dengan norma dan ketentuan yang berlaku; (2) Pembiasaan berbicara dan berkata yang santun sesuai dengan mitra bicara; (3) Pembiasaan berpakaian, berbicara, dan bertingkah laku yang sesuai dengan norma dan ketentuan yang berlaku; (4) Pembiasaan perilaku jujur dan "self discipline" serta menerima konsekwenssi dari perilaku yang melanggar aturan.

Dalam pendidikan karakter di sekolah, semua komponen (pemangku pendidikan) harus dilibatkan, termasuk komponenkornponen pendidikan itu sendiri, yaitu isi kurikulum, proses pembelajaran dan penilaian, penanganan atau pengelolaan mata pelajaran, pengelolaan sekolah, pelaksanaan aktivitas atau kegiatan ko-kurikuler, pemberdayaan sarana prasarana, pembiayaan, dan ethos kerja seluruh warga sekolah lingkungan. Di samping itu, pendidikan karakter dimaknai sebagai suatu perilaku warga sekolah yang dalam menyelenggarakan pendidikan harus berkarakter. Menurut David Elkind \& Freddy Sweet (2004), pendidikan karakter dimaknai sebagai berikut: "character education is the deliberate effort to help people understand, care about, and act upon core ethical values. When we think about the kind of character we want for our children, it is clear that we want them to be able to judge what is right, care deeply about what is right, and then do what they believe to be right, even in the face of pressure from without and temptation from within".

Pendidikan karakter dapat diintegrasikan dalam pembelajaran pada setiap mata pelajaran. Materi pembelajaran yang berkaitan dengan norma atau nilai-nilai pada setiap mata pelajaran perlu dikembangkan, dieksplisitkan, dikaitkan dengan konteks kehidupan sehari-hari. Dengan demikian, pembelajaran nilainilai karakter tidak hanya pada tataran kognitif, tetapi menyentuh pada intemalisasi, dan pengamalan nyata 
dalam kehidupan peserta didik seharihari di masyarakat. Kegiatan ekstra kurikuler yang selama ini diselenggarakan sekolah merupakan salah satu media yang potensial untuk pembinaan karakter dan peningkatan mutu akademik peserta didik. Kegiatan Ekstra Kurikuler merupakan kegiatan pendidikan di luar mata pelajaran untuk membantu pengembangan peserta didik sesuai dengan kebutuhan, potensi, bakat, dan minat mereka melalui kegiatan yang secara khusus diselenggarakan oleh pendidik dan atau tenaga kependidikan yang berkemampuan dan berkewenangan di sekolah. Melalui kegiatan ekstra kurikuler diharapkan dapat mengembangkan kemampuan dan rasa tanggung jawab sosial, serta potensi dan prestasi peserta didik.

Pendidikan karakter di sekolah
juga sangat terkait dengan manajemen atau pengelolaan sekolah. Pengelolaan yang dimaksud adalah bagaimana pendidikan karakter direncanakan, dilaksanakan, dan dikendalikan dalam kegiatankegiatan pendidikan di sekolah secara memadai. Pengelolaan tersebut antara lain meliputi, nilai-nilai yang perlu ditanamkan, muatan kurikulum, pembelajaran, penilaian, pendidik dan tenaga kependidikan, dan komponen terkait lainnya. Dengan demikian, manajemen sekolah merupakan salah satu media yang efektif dalam pendidikan karakter di sekolah. Pendidikan karakter seharusnya membawa peserta didik ke pengenalan nilai secara kognitif, penghayatan nilai secara afektif, dan akhimya ke pengamalan nilai secara nyata. Permasalahan pendidikan karakter yang selama ini ada perlu segera dikaji, dan dicari altenatifalternatif solusinya, serta perlu dikembangkannya secara lebih operasional sehingga mudah diimplementasikan di sekolah. Pendidikan karakter bertujuan untuk meningkatkan mutu penyelenggaraan dan hasil pendidikan di sekolah yang mengarah pada pencapaian pembentukan karakter dan akhlak mulia peserta didik secara utuh, terpadu, dan seimbang, sesuai standar kompetensi lulusan. Melalui pendidikan karakter diharapkan peserta didik mampu secara mandiri meningkatkan dan menggunakan pengetahuannya, mengkaji dan menginternalisasi serta mempersonalisasi nilai-nilai karakter dan akhlak mulia sehingga terwujud dalam perilaku sehari-hari. Pendidikan karakter pada tingkatan institusi mengarah pada pembentukan budaya sekolah, yaitu nilai-nilai yang melandasi perilaku, tradisi, kebiasaan keseharian, dan simbol-simbol yang dipraktikkan oleh semua warga sekolah, dan masyarakat sekitar sekolah. Budaya sekolah merupakan ciri khas, karakter atau watak, dan citra sekolah tersebut di mata masyarakat luas.

Lebih lanjut dijelaskan bahwa pendidikan karakter adalah segala sesuatu yang dilakukan guru, yang mampu mempengaruhi karakter peserta didik. Guru membantu membentuk watak peserta didik. Hal ini mencakup keteladanan bagaimana perilaku guru, cara guru berbicara atau menyampaikan materi, bagaimana guru bertoleransi, dan berbagai hal terkait lainnya. Guru memegang peranan strategis terutama dalam upaya membentuk watak bangsa melalui pengembangan kepribadian dan nilai-nilai yang diinginkan. Dari dimensi tersebut, peranan guru sulit digantikan oleh orang lain. Dipandang dari dimensi pembelajaran, peranan guru dalam masyarakat Indonesia tetap dominan 
sekalipun teknologi yang dapat dimanfaatkan dalam proses pembelajaran berkembang amat cepat. Hal ini disebabkan karena ada dimensi-dimensi proses pendidikan, atau lebih khusus bagi proses pembelajaran, yang diperankan oleh guru yang tidak dapat digantikan oleh teknologi.

Sejak dahulu hingga sekarang, guru dalam masyarakat Indonesia terutama di daerah-daerah pedesaan masih memegang peranan amat penting sekalipun status sosial guru di tengah masyarakat sudah berubah. Guru dengan segala keterbatasannya - terutama dari segi status sosial ekonomi - tetap dianggap sebagai pelopor di tengah masyarakatnya. Guru sebagai pengajar lebih menekankan kepada tugas dalam merencanakan dan melaksanakan pengajaran. Tugas dan tanggung jawab guru sebagai pembimbing memberi tekanan kepada tugas memberikan bantuan kepada siswa dalam memecahkan masalah yang dihadapinya. Tugas dan tanggung jawab sebagai administrator kelas pada hakekatnya merupakan jalinan antara ketatalaksanaan bidang pengajaran dan ketatalaksanaan pada umumnya. Tanggung jawab mengembangkan kurikulum membawa implikasi bahwa guru dituntut untuk selalu mencari gagasan-gagasan

baru,penyempumaan praktek pendidikan, khususnya dalam praktik pengajaran. Tanggung jawab mengembangkan profesi pada dasamya ialah tuntutan dan panggilan untuk selalu mencintai, menghargai, menjaga, dan meningkatkan tugas dan tanggung jawab profesinya. Tanggung jawab dalam membina hubungan dengan masyarakat berarti guru harus dapat berperan menempatkan sekolah sebagai bagian integral dari masyarakat serta sekolah sebagai pembaharu masyarakat.

Guru yang profesional adalah guru yang dapat melakukan tugas mengajamya dengan baik. Dalam mengajar diperlukan kemampuan/kompetensi dan keterampilan-keterampilan yang dibutuhkan untuk kelancaran proses belajar mengajar secara efektif dan efisien. Kriteria guru profesional yang bermutu, antara lain: (1) Menguasai disiplin ilmu dan program kurikulum sekolah, (2) memahami karakteristik peserta didik, (3) menguasai landasan pendidikan dan metodologi pembelajaran yang mendidik, (4) menguasai penggunaan TIK dan PTK, (5) mengembangkan kemampuan diri dan profesi secara terus menerus, dan (6) menjadi model (teladan) bagi siswa dalam perilaku keseharian.

Adapun fungsi strategis guru dalam pendidikan karakter mulia, antara lain: Mengidentifikasikan kebutuhan dan potensi dominan peserta didik sebagai dasar untuk pengembangan program pembeljaran pendidikan karakter mulia; Mengembangkanprogram

belajar/substansi pendidikan karakter mulia secara terpadu ke dalam semua mata pelajaran atau mata pelajaran yang diampunya; Membelajarkan peserta didik secara regular melalui pembimbingan, pembiasaan dan keteledanan dalam keseluruhan proses pembeljaran Melakukan evaluasi yang regular dan berkelanjutan terhadap perkembangan perilaku peserta didik dalam berbagai kondisi social di sekolah; Membangun kemitraan yang harmonis dengan orang tua peserta didik dalam mensupervisi perilkau anak di luar sekolah. 


\section{B. Pendidikan Karakter dalam Pembelajaran Inovatif}

Pendapat yang menyatakan bahwa mengajar adalah proses penyampaian atau penerusan pengetahuan, sudah ditinggalkan oleh banyak orang. Kini, mengajar lebih sering dimaknai sebagai perbuatan yang kompleks, yaitu penggunaan secara integratif sejumlah keterampilan untuk menyampaikan pesan. Pengintegrasian keterampilanketerampilan yang dimaksud dilandasi oleh seperangkat teori dan diarahkan oleh suatu wawasan. Sedangkan aplikasinya secara unik dalam arti secara simultan dipengaruhi oleh semua komponen belajar mengajar. Komponen yang dimaksud yaitu: tujuan yang ingin dicapai, pesan yang ingin disampaikan, subjek didik, fasilitas dan lingkungan belajar, serta yang tidak kalah pentingnya keterampilan, kebiasaan serta wawasan guru tentang diri dan misinya sebagai pendidik. Agar proses pembelajaran dapat berlangsung dengan baik, maka pengajar harus memberdayakan diri sendiri dan para siswanya. Guru harus mampu melakukan pembelajaran inovatif yang ditandai dnegan adanya proses interaksi antara peserta didik dan guru dnegan mengadopsi berbagai strategi ataupun teknologi sesuai dengan kebutuhan peserta didik, sehingga proses belajar siswa menjadi lebih atraktif, menyennagkan, dan efektif dalam mencapai tujuan belajar yang ditetapkan.

Kemajuan ilmu pengetahuan dan teknologi, khususnya menyangkut dengan teori pembelajaran telah banyak mendorong dan mengilhami terhadap inovasi di bidang modelmodel pembelajaran. Pergeseran dari istilah "mengajar, belajar, proses belajar mengajar" kepada "pembelajaran"semestinya tidak hanya di lihat dari sekedar perubahan, akan tetapi mendalam dan harus difahami landasan filosofi dan pergeseran paradigma yang terkandung didalamnya. Pembelajaran merupakan sebuah istilah yang kadang-kadang mengundang kontraversi baik di kalangan para ahli maupun di lapangan, terutama di antara guruguru di sekolah. Sebahagian pendapat mengatakan bahwa istilah pembelajaran sesungguhnya hanya berlaku di kalangan pendidikan masyarakat bukan di lingkungan sekolah, di lain pihak justru istilah tersebut sangat relevan dalam sistem persekolahan, yakni untuk membelajarkan siswa. Pendapat lain bahwa pembelajaran merupakan padanan dari "instruction", yang artinya lebih luas dari pengajaran.

Pembelajaran tidak hanya berlaku dalam pendidikan melainkan dalam pelatihan atau upaya pembelajaran diri. Pembelajaran yang merupakan serangkaian kegiatan yang dirancang untuk memungkinkan terjadinya proses belajar pada siswa. Implikasinya bahwa pembelajaran sebagai suatu proses harus dirancang, dikembangkan dan dikelola secara kreatif, dinamis,dan inoovatif dengan menerapkan pendekatan multi untuk menciptakan suasana dan proses pembelajaran yang kondusif bagi siswa. Pembelajaran sebagai suatu sistem atau proses membelajarkan siswa yang direncanakan, dilaksanakan, dan dievaluasi secara sistematis agar pembelajar dapat mencapai tujuan pembelajaran secara aktif, efektif, dan inovatif. Pembelajaran merupakan sesuatu yang kompleks, artinya segala sesuatu yang terjadi pada proses pembelajaran harus merupakan sesuatu yang sangat 
berarti baik ucapan, pikiran maupun tindakan. Secara umum pembelajaran modern yang diperkirakan akan mewarnai pelaksanaan kurikulum dan pembelajaran di sekolah-sekolah dimasa mendatang, yaitu pembelajaran kuantum, pembelajaran berbasis kompetensi, dan pembelajaran konstektual serta pembelajaran berbasis komputer.

Dimensi pengembangan konteks pembelajaran kuantum yaitu suasana belajar yang menyenangkan, landasan yang kukuh, lingkungan yang mendukung dan rancangan belajar yang dinamis. Keempat unsur ini merupakan interaksi kekuatan yang mendukung kesuksesan belajar yang optimal. Pembelajaran kompetensi menekankan pencapaian standar kompetensi yang diurai menjadi kemampuan dasar yang diurai menjadi beberapa materi pelajaran yang cakupannya beberapa indikator. Pembelajaran Kontekstual (CTL) merupakan suatu model pembelajaran yang menekankan keterlibatan siswa setiap tahapan pembelajaran dengan cara menghubungkannya dengan situasi kehidupan yang dialami siswa sehari-hari sehingga pemahaman materi diterapkan dalam kehidupan nyata. Pembelajaran dengan memanfaatkan sarana teknologi imformasi melalui jaringan internet merupakan salah satu alternatif yang tepat dan dapat mengatasi berbagai persoalan pembelajaran, walaupun sistem pendidikan di Indonesia keberadaannya sangat hetrogen karena terbentur masalah letak geografis yang sangat besar pengaruhnya terhadap kemajuan teknologi informasi.

Apapun model pembelajaran yang dilakukan oleh guru dalam proses pelaksanaan pembelajarannya hendaknya memperhatikan "langkah 5 S" proses pembentukan karakter mulia, sebagai berikut: Sapalah setiap siswa dengan ramah; Berilah Senyum yang menawan kepada siswa setiap kali mereka datang; Sampaikan Salam yang hangat kepada siswa setiap kali memulai pembelajaran; Perlihatkan sikap dan perilaku Sabar, setiap kali menghadapi siswa yang nakal atau bandel, atau menghadapi musibah; Perlihatkan rasa syukur yang wajar apabila mendapat nikmat atau siswa berhasil dalam belajarnya.

\section{Kesimpulan}

Guru merupakan salah satu faktor kunci dalam meletakkan dasardasar, yang kokoh bagi pembentukan karakter generasi bangsa yang mulia melalui pembelajaran inovatif sesuai dengan perkembangan mental psikologis peserta didik pada setap jenis dan jenjang pendidikan formal. Pemahaman guru yang komprehensif tentang konsep dan jenis pembelajaran inovatif dalam pendidikan karakter mulia di sekolah merupakan modal dasar dalam mencapai tujuan pendidikan karakter mulia secara efektif.

\section{Daftar Pustaka}

Argyris, Chris. (1999). On Learning Organization, UK: Blackwell Published.

Armstrong, David G. and Tom V. Savage. (1983). Secondary Education. Macmillan Publishing Co., Inc. New York.

Bredekamp, Sue dan Rosegrant, Teresa (eds). (1992). Reaching Potentials: Appropriate

Curriculum and Assessmentfor Young Children, Vol. 1. Washington DC: National Association for the Education of Young Children.

Catler, A.B. \& Ruopp, F.N. (1993). Buying Timefor Teacher Professional Development. 
Educational Leadership, Vol 6, 50, March

Delors, Jacques. (1996). "Learning": The Treasure Within, Report to UNESCO of the International Commission on Education for the Twenty-First Century. Paris: UNESCO Publishing

Duke, Nell, K. (2003). Information Books in Early Childhood. NAEYC

Firestone, W.A. (1993). "Why 'Professionalizing' Teaching Is Not Enough?" Educational Leadership No.6, Vol. 50, March

Fogarty, Robin. (1991). The Mindful School: How to Integrated the Curricula. Palatine, IL: Skylight Publishing.

Goble, N.M. (1977). The Changing Role of the Teacher. Paris: UNESCO

Hallack, J. (1990). Investing in the Future: Setting Educational Priorities in the Developing World. Paris: UNESCO

Hoover, K.H. (1976). The Professional Teacher's Handbook: A Guide for Improving Instruction in Today's Middle and Secondary Schools, Sydney: Allyn and Bacon

Joyce, Bruce \& Well, Marsha. (1996). Models of Teaching. Englewood Clifs. New Jersey: Prentice Hall Inc.

Katz, Lilian. G. (1993). Multiple Perspectives on the Quality of Early Chilhood Programs. ERIC Digest. ED355041

Langford, David P. dan Cleary, Barbara A. (1996). Orchestrating Learning with Quality. Kualalumpur: Synergy Books International

Marquardt, Michael dan Angus Reynolds. (1994). Global Learning Organization: Gaining Competitive Advantage Through
Continuous Learning, New York: Irwin Professional Publishing

NAEYC. (2003). Early Chilhood Curriculum, Assessment, and Program Evaluation. NAEYC. November

National Association of Elementary School Principals. (1994). Standards for Quality Elementary and Middle Schools: Kindergarten through Eightd Grade. Alexandria, VA NAESP, 1-800-38 NAESP

Peraturan Menteri Pendidikan Nasional Nomor 22,23,24 Tahun 2006.

Power, C.N. (1996). Enchancing the Role of Teachers in a Changing World. Paris: UNESCO

Print, Murray. (1993). Curriculum Development and Design. Australia: Allen \& Unwin Pty Ltd. St. Leonad.

Sallis, Edward. (1993). Total Quality Management in Education, New Jersey: Englewood Cliffs: Prentice Hall Inc.

Stainback S. dan Stainback W. (1992). Curriculum

Considerations in Inclusive

Classroom: Facilitating Learningfor All Students. Baltimore: Paul Brookes.

Udin S.Saud (2007). Kurikulum Pendidikan Dasar Masa Depan. Makalah disajikan dalam Seminar Nasional Kurikulum Pendidikan Masa Depan, diselenggarakan oleh Pusat Kurikulum Balitbang Diknas. Bogor, Maret 2007.

(2007). Problematika Keberlangsungan Pendidikan Anak Usia Dini dan Pendidikan Dasar. Makalah disajikan dalam Seminar Nasional Pengembangan Pendidikan Dasar, diselenggarakan oleh 
FKIP Universitas Riau,

Pekanbaru, 12-13 April 2007.

UNESCO. 1996. What Makes a Good

Teacher? Children Speak Their Minds. Paris

World Bank, 1989. Indonesia:

Streangthening the Quality of

Teacher Education. Draft

Technical Paper, Asia Region 